\title{
Evaluation of Innovation Ecosystem in High-Tech Industry Based on Factor Analysis
}

\author{
Jianghui Lei \\ Dept. School of Management \\ Wuhan University of Science and Technology \\ Wuhan, China \\ 787595332@qq.com
}

\author{
Xudong Deng \\ Dept. School of Management \\ Wuhan University of Science and Technology \\ Wuhan, China \\ dengxudong@wust.edu.cn
}

\author{
Shaowei $\mathrm{Lu}$ \\ Dept. School of Management \\ Wuhan University of Science and Technology \\ Wuhan, China \\ 279640298@qq.com
}

\begin{abstract}
This paper selects the factors that influence the development of high-tech industry from the perspective of innovation ecosystem and uses the factor analysis method to evaluate the innovation factor of high-tech industry. And ultimately the factor of high-tech industry innovation output, innovation achievements transformation and innovation support is extracted. It is found that the key to the development of hightech industry lies in the effective transformation of innovation achievements in high-tech industries, including effective output of innovative products and effective input of innovative capital. Under the guidance of innovation results and innovation process, the author proposes to enhance innovation technology, train creative talents, and transform extensive innovation investmentoutput economic growth mode and innovative management concept and countermeasures. Compared with the previous research, the article is more profound evaluation of the current development of high-tech industry. On the basis of researching the innovation factors of high-tech industry, the development countermeasures of high-tech industry are put forward.
\end{abstract}

Keywords-High-tech industry; innovation ecosystem; innovation factor; factor analysis

\section{INTRODUCTION}

The development of high-tech industry can reflect the comprehensive competitiveness of a country or region and plays an important role in stimulating the growth of national economy. The development trend of high and new technology industry is swift and violent.

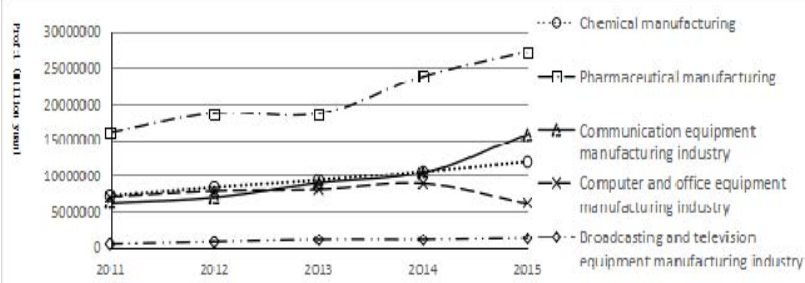

Fig. 1. 2011-2015 Total profit for High-tech industries
But from the development level and speed of the high-tech industry, there is a big difference between the industries, as shown in the high-tech industry selected in Fig. 1. The development of each industry has its own characteristics. In different environments, it eventually presents different development status.

\section{EMPIRICAL STUDY}

This paper analyzes the 15 common indexes of five major categories of high - tech industry through SPSS. Through the extraction of the main factors, the author shows the new factors on the impact of various high-tech industries and the overall evaluation of the development of various industries under the new evaluation indicators.

\section{A. Innovation System of High-tech Industry Innovation Ecosystem}

TABLE I. INDEX SYSTEM OF INFLUENCING FACTORS OF INNOVATIVE ECOSYSTEM IN HIGH - TECH INDUSTRY

\begin{tabular}{|c|c|c|}
\hline $\begin{array}{c}\text { First level } \\
\text { index }\end{array}$ & Two level index & Three level index \\
\hline \multirow{5}{*}{$\begin{array}{c}\text { Innovative } \\
\text { state }\end{array}$} & \multirow{4}{*}{ Capital status } & R\&D internal spending funding $X_{1}$ \\
\hline & & Amount of investment $\mathrm{X}_{2}$ \\
\hline & & New fixed assets $X_{3}$ \\
\hline & & $\mathrm{R} \& \mathrm{D}$ project funding $\mathrm{X}_{4}$ \\
\hline & Talent status & $\begin{array}{l}\text { R\&D personnel equivalent to full time equivalent } \\
\text { of } \mathrm{X}_{5}\end{array}$ \\
\hline \multirow{8}{*}{$\begin{array}{c}\text { Innovation } \\
\text { potential }\end{array}$} & \multirow{4}{*}{ Material potential } & Number of enterprises $\mathrm{X}_{6}$ \\
\hline & & Number of $\mathrm{R} \& \mathrm{D}$ institutions $\mathrm{X}_{7}$ \\
\hline & & Number of new product development projects $\mathrm{X}_{8}$ \\
\hline & & $\begin{array}{l}\text { The total number of projects completed and put } \\
\text { into operation } \mathrm{X}_{9}\end{array}$ \\
\hline & \multirow{3}{*}{ Fund potential } & Main business income $\mathrm{X}_{10}$ \\
\hline & & Total profit $\mathrm{X}_{11}$ \\
\hline & & New product sales revenue $\mathrm{X}_{12}$ \\
\hline & $\begin{array}{l}\text { Technological } \\
\text { potential }\end{array}$ & Number of patent applications $X_{13}$ \\
\hline \multirow{2}{*}{$\begin{array}{c}\text { Innovation } \\
\text { flow }\end{array}$} & \multirow{2}{*}{ Technology flow } & Technology introduction expenditure $\mathrm{X}_{14}$ \\
\hline & & Purchase of domestic technology expenditure $\mathrm{X}_{15}$ \\
\hline
\end{tabular}


There are mainly two research perspectives on the innovation factors of high and new technology industry. One is from the angle of efficiency to analyze and evaluate the influencing factors of high-tech industry. Liu Wei adopts the three-stage DEA model to study the influence of environmental factors on the innovation efficiency of high-tech industry and obtains the positive correlation between environmental factors and innovation efficiency[1]. Using the SFA method to study the single factor to the high and new technology industry innovation efficiency influence, Li Xinchun extracts the labor and the fund two factors[2]. The other one is to study the factors affecting the development of high-tech industry from the ecological perspective. From the perspective of innovation ecosystem for empirical research on 53 national science and Technology Park, Chen Xiangdong and Liu Zhichun puts forward relevant countermeasures to improve the comprehensive level of science and Technology Park[3]. Using case analysis methods, Lv Yibo declassified the growth genes of iOS, Android and Symbian from the perspective of open innovation ecosystem[4]. The research point of validity is to improve the innovation technology and the research from the ecological point of view focuses on optimizing the innovation input input-output system. The existing research focuses on the impact factors of high and new technology industry, focusing on the development evaluation of a certain area[5], an industry[6] and the provinces and cities nationwide[7] hightech industry. On the basis of previous studies, the 15 indicators are classified according to the innovation state, innovation potential and innovation flow in the innovation ecosystem[8][9]. The index system as shown in table 1 is obtained, such as number of enterprises, main business income and so on.

\section{B. Sample Data Detection}

The sample is derived from the 2015 statistics of China Science and Technology Statistics Yearbook. The data of 25 high-tech industries are measured by KMO and Bartlett sphericity. The results are shown in table 2. Test result shows that the observation of Bartlett ball detection statistics is 1198.125 and the probability of the corresponding P- close to 0 If the significance level is 0.05 and the probability of P- less than 0.05 , it shows that the correlation coefficient matrix is significantly different from the unit matrix. The KMO value is 0.828. According to the KMO measurement standard, the original sample is more suitable for factor analysis.

TABLE II. KMO AND BARTLETT IDENTIFICATION

\begin{tabular}{|c|c|c|}
\hline Take the sufficient degree of the Kaiser-Meyer-Olkin metric & 0.828 \\
\hline \multirow{2}{*}{$\begin{array}{c}\text { Bartlett } \\
\text { test of sphericity }\end{array}$} & About chi square & 1198.125 \\
\cline { 2 - 3 } & $\boldsymbol{d f}$ & 105 \\
\cline { 2 - 3 } & Saliency & 0.000 \\
\hline
\end{tabular}

\section{Extraction Factor}

According to the correlation coefficient matrix of the original variable, the article specifies the extraction of three eigenvalues. The analysis results are shown in table 3. From the second column data, it can see that the common degree of all variables at this time is higher and the information loss of each variable is less. Therefore, the overall effect of this factor is ideal.
TABLE III. FACTOR COHERENCE IN ANALYSIS

\begin{tabular}{|c|c|c|}
\hline & Start & Capture \\
\hline $\mathrm{X}_{5}$ & 1 & 0.995 \\
\hline $\mathrm{X}_{15}$ & 1 & 0.982 \\
\hline $\mathrm{X}_{8}$ & 1 & 0.984 \\
\hline $\mathrm{X}_{14}$ & 1 & 0.965 \\
\hline $\mathrm{X}_{9}$ & 1 & 0.992 \\
\hline $\mathrm{X}_{3}$ & 1 & 0.984 \\
\hline $\mathrm{X}_{1}$ & 1 & 0.986 \\
\hline $\mathrm{X}_{13}$ & 1 & 0.968 \\
\hline $\mathrm{X}_{2}$ & 1 & 0.976 \\
\hline $\mathrm{X}_{11}$ & 1 & 0.955 \\
\hline $\mathrm{X}_{4}$ & 1 & 0.984 \\
\hline $\mathrm{X}_{6}$ & 1 & 0.976 \\
\hline $\mathrm{X}_{10}$ & 1 & 0.963 \\
\hline $\mathrm{X}_{7}$ & 1 & 0.983 \\
\hline $\mathrm{X}_{12}$ & 1 & 0.982 \\
\hline
\end{tabular}

According to the correlation coefficient matrix of the original variable, the eigenvalue and contribution rate shown in table 4 are obtained by factor analysis method. The second column to fourth column data item describes the initial solution of the factor analysis. The fifth column to seventh column data item describes the condition of the factor solution. The eighth column to the tenth column series describes the final factor solution.

TABLE IV. FACTORS EXPLAINING THE TOTAL VARIANCE OF ORIGINAL VARIABLES

\begin{tabular}{|c|c|c|c|c|c|c|c|c|c|}
\hline \multirow{2}{*}{ element } & \multicolumn{3}{|c|}{ Initial eigenvalue } & \multicolumn{3}{c|}{$\begin{array}{c}\text { Extract sum of } \\
\text { squares load }\end{array}$} & \multicolumn{3}{c|}{$\begin{array}{c}\text { Cyclic sum of sum } \\
\text { loading }\end{array}$} \\
\hline 1 & 12.874 & 85.829 & 85.829 & 12.874 & 85.829 & 85.829 & 7.055 & 47.031 & 47.031 \\
\hline 2 & 1.406 & 9.371 & 95.2 & 1.406 & 9.371 & 95.2 & 3.876 & 25.842 & 72.873 \\
\hline 3 & 0.395 & 2.63 & 97.831 & 0.395 & 2.63 & 97.831 & 3.744 & 24.958 & 97.831 \\
\hline 4 & 0.158 & 1.051 & 98.882 & & & & & & \\
\hline 5 & 0.074 & 0.491 & 99.372 & & & & & & \\
\hline 6 & 0.059 & 0.39 & 99.762 & & & & & & \\
\hline 7 & 0.019 & 0.126 & 99.888 & & & & & & \\
\hline 8 & 0.008 & 0.052 & 99.94 & & & & & & \\
\hline 9 & 0.005 & 0.034 & 99.974 & & & & & & \\
\hline 10 & 0.003 & 0.02 & 99.994 & & & & & & \\
\hline 11 & 0 & 0.002 & 99.996 & & & & & & \\
\hline 12 & 0 & 0.002 & 99.998 & & & & & & \\
\hline 13 & 0 & 0.001 & 99.999 & & & & & & \\
\hline 14 & $5.43 \mathrm{E}-05$ & 0 & 100 & & & & & & \\
\hline 15 & $4.53 \mathrm{E}-05$ & 0 & 100 & & & & & & \\
\hline
\end{tabular}

\section{Factor Nomenclature}

TABLE V. COMPONENT SCORE COVARIANCE MATRIX

\begin{tabular}{|c|c|c|c|}
\hline element & $\mathbf{1}$ & $\mathbf{2}$ & $\mathbf{3}$ \\
\hline 1 & 1 & 0 & 0 \\
\hline 2 & 0 & 1 & 0 \\
\hline 3 & 0 & 0 & 1 \\
\hline
\end{tabular}

The table 5 component score covariance matrix shows that the correlation between the 3 factors has been lost, so it can be named and analyzed. 
TABLE VI. ROTATION ELEMENT MatriX

\begin{tabular}{|c|c|c|c|}
\hline & \multicolumn{3}{|c|}{ element } \\
\cline { 2 - 4 } & $\mathbf{1}$ & $\mathbf{2}$ & $\mathbf{3}$ \\
\hline $\mathrm{X}_{9}$ & 0.931 & 0.239 & 0.261 \\
\hline $\mathrm{X}_{8}$ & 0.903 & 0.278 & 0.302 \\
\hline $\mathrm{X}_{3}$ & 0.888 & 0.287 & 0.338 \\
\hline $\mathrm{X}_{7}$ & 0.878 & 0.275 & 0.369 \\
\hline $\mathrm{X}_{6}$ & 0.87 & 0.292 & 0.366 \\
\hline $\mathrm{X}_{2}$ & 0.867 & 0.316 & 0.351 \\
\hline $\mathrm{X}_{11}$ & 0.745 & 0.446 & 0.447 \\
\hline $\mathrm{X}_{10}$ & 0.58 & 0.576 & 0.543 \\
\hline $\mathrm{X}_{15}$ & 0.272 & 0.926 & 0.226 \\
\hline $\mathrm{X}_{14}$ & 0.291 & 0.837 & 0.424 \\
\hline $\mathrm{X}_{12}$ & 0.355 & 0.699 & 0.606 \\
\hline $\mathrm{X}_{1}$ & 0.493 & 0.464 & 0.727 \\
\hline $\mathrm{X}_{4}$ & 0.484 & 0.471 & 0.727 \\
\hline $\mathrm{X}_{13}$ & 0.54 & 0.438 & 0.696 \\
\hline $\mathrm{X}_{5}$ & 0.599 & 0.44 & 0.665 \\
\hline
\end{tabular}

In order to make the factor has the naming explanatory nature, orthogonal transform of the factor load matrix is carried out by using the variance method. The analysis results are shown in table 6 . The first factor mainly explains the number of completed projects, the number of new product development projects, the number of new fixed assets, R \& D institutions, the number of enterprises, the amount of investment, the total profit and the revenue of the main business. It can be named as innovation output of hi-tech industry $\left(\mathrm{F}_{1}\right)$. The second factor explains the purchase of domestic technology expenditure, technology introduction, expenditure and new product sales revenue. It can be named as high-tech industry innovation achievements transformation $\left(\mathrm{F}_{2}\right)$.

TABLE VII. FACTOR SCORE COEFFICIENT MATRIX

\begin{tabular}{|c|c|c|c|}
\hline & \multicolumn{3}{|c|}{ element } \\
\cline { 2 - 4 } & $\mathbf{1}$ & $\mathbf{2}$ & $\mathbf{3}$ \\
\hline $\mathrm{X}_{5}$ & -0.075 & -0.168 & 0.414 \\
\hline $\mathrm{X}_{15}$ & -0.006 & 0.807 & -0.653 \\
\hline $\mathrm{X}_{8}$ & 0.262 & 0 & -0.22 \\
\hline $\mathrm{X}_{14}$ & -0.1 & 0.514 & -0.23 \\
\hline $\mathrm{X}_{9}$ & 0.297 & -0.004 & -0.268 \\
\hline $\mathrm{X}_{3}$ & 0.236 & -0.025 & -0.158 \\
\hline $\mathrm{X}_{1}$ & -0.157 & -0.199 & 0.552 \\
\hline $\mathrm{X}_{13}$ & -0.119 & -0.2 & 0.501 \\
\hline $\mathrm{X}_{2}$ & 0.219 & -0.004 & -0.153 \\
\hline $\mathrm{X}_{11}$ & 0.109 & 0.049 & -0.049 \\
\hline $\mathrm{X}_{4}$ & -0.162 & -0.192 & 0.55 \\
\hline $\mathrm{X}_{6}$ & 0.212 & -0.047 & -0.104 \\
\hline $\mathrm{X}_{10}$ & -0.022 & 0.102 & 0.079 \\
\hline $\mathrm{X}_{7}$ & 0.215 & -0.069 & -0.087 \\
\hline $\mathrm{X}_{12}$ & -0.163 & 0.183 & 0.185 \\
\hline $\mathrm{fac}$ & & & \\
\hline
\end{tabular}

The third factor mainly explains the research and experimental funds, internal expenditure, research and experimental projects, the number of patent applications and the equivalent time between the research and the experimental personnel. It can be named as high-tech industry innovation support $\left(\mathrm{F}_{3}\right)$. Simultaneously, estimation of Factor Score Coefficient was estimated by regression method. The specific results were shown in table 7 .

\section{High-TECH INDUSTRY EVALUATION AND ANALYSIS}

\section{A. High and New Technology Industry Evaluation}

According to the scoring function of the above factors, the $F_{1}, F_{2}$ and $F_{3}$ values of 25 industries were calculated by using EXCEL. Considering the quantity, the variance contribution rate of the 3 factors in table 4 is taken as the weighting factor to get the comprehensive score of the impact factor of the hightech industry( $\mathrm{F})$.

$$
\mathrm{F}=0.47031 \mathrm{~F}_{1}+0.25842 \mathrm{~F}_{2}+0.24958 \mathrm{~F}_{3}
$$

The calculated results and factor rankings are shown in table 8 .

TABLE VIII. COMPREHENSIVE EVALUATION OF INFLUENCING FACTORS OF HigH AND NEW TECHNOLOGY INDUSTRY

\begin{tabular}{|l|c|c|c|c|}
\hline \multirow{2}{*}{ Industry } & \multicolumn{3}{|c|}{ Factor ranking } \\
\cline { 2 - 6 } & $\boldsymbol{F}_{\mathbf{1}}$ & $\boldsymbol{F}_{2}$ & $\boldsymbol{F}_{3}$ & $\boldsymbol{F}$ \\
\hline $\begin{array}{l}\text { Electronic and communication equipment manufacturing } \\
\text { industry }\end{array}$ & 25 & 1 & 1 & 1 \\
\hline Communication equipment manufacturing & 24 & 2 & 2 & 2 \\
\hline Communication terminal equipment manufacturing & 23 & 3 & 3 & 3 \\
\hline Computer and office equipment manufacturing & 21 & 4 & 6 & 4 \\
\hline Communication system equipment manufacturing & 22 & 7 & 4 & 5 \\
\hline Pharmaceutical manufacturing & 20 & 6 & 5 & 6 \\
\hline Electronic device manufacturing & 19 & 8 & 7 & 7 \\
\hline Computer manufacturing & 18 & 5 & 8 & 8 \\
\hline Electronic component manufacturing & 17 & 10 & 9 & 9 \\
\hline Audiovisual equipment manufacturing & 16 & 9 & 11 & 10 \\
\hline Chemical manufacturing & 15 & 11 & 10 & 11 \\
\hline Medical instrument and instrument manufacturing industry & 14 & 12 & 12 & 12 \\
\hline Instrument manufacturing & 13 & 13 & 13 & 13 \\
\hline Aviation, spacecraft and equipment manufacturing & 12 & 14 & 14 & 14 \\
\hline Aircraft manufacturing & 11 & 16 & 15 & 15 \\
\hline Proprietary Chinese medicine production & 10 & 15 & 16 & 16 \\
\hline Other electronic equipment manufacturing & 9 & 17 & 17 & 17 \\
\hline Integrated circuit manufacturing & 8 & 18 & 18 & 18 \\
\hline Biopharmaceutical manufacturing & 7 & 19 & 19 & 19 \\
\hline Manufacture of medical instruments and apparatus & 6 & 21 & 20 & 20 \\
\hline Manufacture of radio and television equipment & 4 & 20 & 21 & 21 \\
\hline Computer parts manufacturing & 3 & 23 & 22 & 22 \\
\hline Semiconductor discrete device fabrication & 2 & 25 & 24 & 24 \\
\hline Spacecraft manufacturing & 1 & 24 & 25 & 25 \\
\hline Manufacture of electronic vacuum devices & & \\
\hline
\end{tabular}

\section{B. High and New Technology Industry Analysis}

According to the weight coefficient of the 3 factors, the weight of $F_{1}$ is 0.47031 , the weight of $F_{2}$ is 0.25842 and the weight of $F_{3}$ is $0.24958 . F_{1}$ has the greatest influence. $F_{2}$ 's influence is central. $\mathrm{F}_{3}$ 's influence is minimal. According to the weight coefficient, the higher the $F_{1}$ score, the higher the overall ranking. But from the result of the comprehensive score ranking, the higher the $\mathrm{F}_{1}$ score, the lower the overall ranking. The reason for this phenomenon is that the value of $F_{1}$ is negative. In general, the high-tech industry innovation output capacity is not enough. The support for innovation is not proportional to its support for innovation, which is not fully into innovation and not full of innovations into the innovation ability of income. 


\section{CONCLUSIONS AND COUNTERMEASURES}

The core of the above research is to achieve the innovation support and output effective outcome transformation of high-tech industry. This is not only the pursuit of innovation results, but also the control of the innovation process. In terms of innovation results, this is mainly due to the effective output of innovative products. From the point of view of innovation, it embodies the effective input of innovative capital. The key to ensure the effective output of innovative products is innovation technology and the key to ensure the effective input of innovation capital is the timeliness of capital investment. In view of the above two points, the author puts forward the following opinions. First, strengthen the continuous learning and research of innovative knowledge and technology. It should pay attention to the effective transformation of innovative knowledge and technology. Second, reserving excellent creative talents and giving full play to the value of creative talents. Third, changing the extensive capital input the economic growth mode of output. Fourth, importing more advanced innovative management concepts and improving the management system of high-tech industries.

\section{REFERENCES}

[1] Liu Wei, "Analysis of high tech industry innovation efficiency considering environmental factors -- Based on a comparison between 2000-2007 and two times of 2008-2014," Scientific research management, pp. 19-25, November 2016, (In Chinese).

[2] Li Xinchun, Li Shengwen, Zhang Shujun, "Single factor efficiency of high-tech and non-high tech industry innovation," Chinese industrial economy, pp. 68-77, May 2010, (In Chinese).

[3] Chen Xiangdong, Liu Zhichun, "Observation on the development of science parks in China based on the viewpoint of innovation ecosystem," Chinese Soft Science, pp. 151-161, November 2014, (In Chinese).

[4] Lv Yibo, Lan Qing, Han Shaojie, "Growth genes of open innovation ecosystem: a case study based on IOS, Android and Symbian," Chinese industrial economy, pp. 148-160, May 2015, (In Chinese).

[5] Zhang lanthanum, "Evaluation of industrial development level of Hubei hi tech Development Zone," Statistics and decision making, pp. 55-57, February 2015, (In Chinese).

[6] Liu Chunhui, Zhao Yulin, Dong Dengzhen, "Empirical research on interactive development of science and technology innovation and electronic and communication equipment manufacturing industry," Statistics and decision making, pp. 104-107, August 2016, (In Chinese).

[7] Liu Wei, Chen Jingquan, Li Xingxing, "TFP measurement and convergence trend of technological innovation in China's provincial high-tech industries," Economic theory and economic management, pp. 36-50, January 2013, (In Chinese).

[8] Liu Zhichun, Chen Xiangdong, "Research on the relationship between innovation ecosystem and innovation efficiency in Science Park," Scientific research management, pp. 26-31, February 2015, (In Chinese).

[9] Chen Xiangdong, Liu Zhichun, "Observation on the development of science parks in China based on the viewpoint of innovation ecosystem," Chinese Soft Science, pp. 151-161, November 2014, (In Chinese). 